DOI: 10.17117/na.2016.07.01.381

Поступила (Received): 02.07.2016

Долгих Г.В., Калинин А.Л.

Применение оригинального эмпирического критерия Г.К. Арнольда для расчета безопасных давлений на грунт земляного полотна

\author{
Dolgikh G.V., Kalinin A.L. \\ The use of original empirical criterion G.K. Arnold \\ to calculate safe pressure on the soil subgrade
}

В статье рассмотрен вопрос повышения надежности расчета дорожной конструкции по сопротивлению сдвигу в грунте. Применением критерия безопасных давлений, согласно которому давления, передаваемые дорожной одеждой на земляное полотно не должны превышать безопасной величину. Для решения этой задачи применим уравнение предельного состояния критерия Г.К. Арнольда

Ключевые слова: безопасное давление, главное напряжение, сцепление, угол внутреннего трения

Долгих Геннадий Владимирович

Кандидат технических наук, доцент

Сибирская автомобильно-дорожная академия

2. Омск, пр.т Мира, 5

Калинин Александр Львович

Преподаватель

Сибирская автомобильно-дорожная академия

2. Омск, пр.т Мира, 5
The article examined the issue of increasing the reliability of the calculation of the road construction on the shear strength in the soil. Applying the criteria of safe pressure, whereby the pressure transmitted to the pavement subgrade must not exceed a safe value. To solve this problem we apply the equation of limit state criterion G.K. Arnold

Key words: safe pressure, main voltage, grip, angle of internal friction

Dolgikh Gennadiy Vladimirovich

Candidate of Technical Sciences, Associate Professor Siberian automobile and highway academy

Omsk, Mira ave., 5

\section{Kalinin Aleksandr Lvovich}

Lecturer

Siberian automobile and highway academy

Omsk, Mira ave., 5

Анализируя предельные значения глубин неровностей дорожных покрытий, рекомендуемые нормами и публикациями $[1,2]$ отметим, что они часто оказываются меньше фактических значений, фиксируемых при диагностике дорог. Причина неудовлетворительного состоянии покрытий автомобильных дорог по показателям ровности заключается в накапливании дорожной конструкцией необратимых деформаций [3-8], что свидетельствует о недостаточном сопротивлении асфальтобетонов [9] и грунтов [10,11] сдвигу. Поэтому специалисты вынуждены разрабатывать и модифицировать условия пластичности [12-15], отыскивая опасные комбинации главных напряжений и учитывая в этих критериях эффекты, возникающие от уплотнения $[16,17]$ и усталости грунтов [18, 
19]. Повысить надежность расчета дорожной конструкции по сопротивлению сдвигу в грунте можно применением критерия безопасных давлений, согласно которому давления, передаваемые дорожной одеждой на земляное полотно не должны превышать безопасной величину. Основной задачей такого расчета является определения безопасного давления. Для решения этой задачи применим уравнение предельного состояния критерия Г.К. Арнольда, которое имеет вид:

$$
\frac{1}{2} \cdot\left(\sigma_{1}-\left(\frac{1+\sin \varphi}{1-\sin \varphi}\right) \cdot \sigma_{3}\right)=c,
$$

где $c$ - сцепление, Па; $\varphi$ - угол внутреннего трения;

В уравнении (1) необходимо определить максимальное и минимальное главные напряжения $\sigma_{1}$ и $\sigma_{3}$. Для этого воспользуемся способом, полученным в работах $[20,21]$. Следуя этим работам, минимальное главное напряжение $\sigma_{3}$ выражается через величину максимального главного напряжения $\sigma_{1}$. Расчет главных напряжений выполняют по формулам

$$
\sigma_{1}=p \cdot K ; \sigma_{2}=\sigma_{3}=\alpha \cdot \frac{\mu}{1-\mu} \cdot \sigma_{1} ; \alpha=1-\sqrt{1-K^{2}},
$$

где $p$ - давление на поверхности земляного полотна, Па; $K$ - коэффициент затухания максимального главного напряжения в сечении по оси симметрии нагрузки; $\alpha$ - функция глубины; $\mu$ - коэффициент Пуассона.

Для вывода формулы о величине безопасного давления зависимости (2) нужно подставить в уравнение (1) и решить его относительно давления $p$. Сделав все необходимые процедуры, получим

$$
p_{\sigma}=\frac{1}{1-\left(1+\operatorname{ctg}^{2}\left(\frac{\pi}{4}+\frac{\varphi}{2}\right)\right)^{-1,5}} \cdot\left(\frac{2 \cdot c \cdot \cos \varphi}{\left(1-\sin \varphi-\frac{\mu}{1-\mu}\left(1-\sqrt{1-K_{1}^{2}}\right)(1+\sin \varphi)\right)}\right),
$$

где $K_{1}$ - величина коэффициента $K$ в наиболее опасной точке (точка с наибольшим касательным напряжением по глубине земляного полотна).

\section{Список используемых источников:}

1. Александров А.С. Критерии расчета дорожных конструкций по ровности, допускаемые и предельные неровности // Вестник гражданских инженеров. 2008. №4. С. 97 - 104.

2. Александров А.С., Гордеева С.А., Шпилько Д.Н. О допускаемых и предельных значениях неровностей асфальтобетонных покрытий дорожных одежд жесткого типа //Автомобильная промышленность. 2011. №2. C. 31-35.

3. Александров А.С. Расчет пластических деформаций материалов и грунтов дорожных конструкций при воздействии транспортной нагрузки // Строительная механика инженерных конструкций и сооружений. 2009. №2. С. 3-11.

4. Александров А.С. Нелинейное пластическое деформирование материалов при воздействии повторных кратковременных нагрузок // Известия высших учебных заведений. Строительство. 2008. №10. C. 74-84.

5. Александров А.С. Моделирование деформационных процессов, протекающих в связных грунтах // Наука и техника в дорожной отрасли. 2002. №4. С. 16-19.

6. Александров А.С., Александрова Н.П., Кузин Н.В. Методы теории наследственности в расчетах пластических деформаций материалов и грунтов при воздействии повторяющихся нагрузок // Транспортное строительство. 2009. №2. С. 25-28. 
7. Александров А.С. Обобщающая модель пластического деформирования дискретных материалов дорожных конструкций при воздействии циклических нагрузок // Строительные материалы. 2016. № 5. C. 27-30.

8. Кузин Н.В. Расчет пластических смещений асфальтобетонных порожных покрытий // Молодой ученый. 2016. № 10 (114). С. 253-255.

9. Александров А.С., Долгих Г.В., Калинин А.Л. О допускаемых давлениях на грунты земляного полотна и слои дорожной одежды // Наука и техника в дорожной отрасли. 2012. № 2. С. 10 - 13.

10. Долгих Г.В. Применение критерия безопасных давлений для расчета дорожных конструкций по сопротивлению сдвигу в грунте земляного полотна // В сборнике: Политранспортные системы материалы VIII Международной научно-технической конференции в рамках года науки Россия - EC. Новоси-бирск: СГУПС, 2015. С. 176-182.

11. Александрова Н.П., Чусов В.В. Особенности расчета асфальтобетонных покрытий по сопротивлению сдвигу с учетом накапливания повреждений // Вестник Сибирской государственной автомобильно-дорожной академии. 2016. № 3 (49). С. 42 - 50.

12. Александрова Н.П., Семенова Т.В. Совершенствование методов экспресс контроля уплотнения грунтов в земляном полотне лесных дорог. Часть 1. Обобщающая математическая модель // Международный научно-исследовательский журнал. 2016. № 6(48). С. 10-14.

13. Александрова Н.П., Семенова Т.В., Долгих Г.В. Методы определения максимальной плотности грунтов земляного полотна автомобильных дорог. Омск: СибАДИ, 2015

URL: http://bek.sibadi.org/fulltext/ESD53.pdf

14. Александров А.С., Александрова Н.П., Долгих Г.В. Учет влияния усталости на параметры материала критерия Кулона-Мора Часть 1. Вывод математических моделей // Вестник научных конференций. 2016. № 6-3 (10). С. 7-8.

15. Александров А.С., Александрова Н.П., Долгих Г.В. Учет влияния усталости на параметры материала критерия Кулона-Мора Часть 2. Параметры математических моделей // Вестник научных конференций. 2016. № 6-3 (10). С. 8-9.

16. Александров А.С., Долгих Г.В. Модификация критерия Кулона - Мора для расчета конструкций лесных дорог по сопротивлению сдвигу. Часть 1. Ввод третьего параметра материала // Международный научно-исследовательский журнал. 2016. № 6-2 (48). С. 6-9.

17. Александров А.С., Долгих Г.В., Александрова Н.П. Модифицированный критерий Кулона - Мора. Часть 1. Вывод уравнения предельного равновесия // Вестник научных конференций. 2016. № 5-4 (9). C. 17-18.

18. Александров А.С., Долгих Г.В., Александрова Н.П. Модифицированный критерий Кулона - Мора. Часть 2. Круги предельных напряжений // Вестник научных конференций. 2016. № 5-4 (9). С. 18-20. 19. Александров А.С., Долгих Г.В., Александрова Н.П. Модифицированный критерий Кулона - Мора. Часть 3. Экспериментальное определение величины третьего параметра // Вестник научных конференций. 2016. № 5-4 (9). С. 20-21.

20. Александров А.С., Долгих Г.В., Александрова Н.П. Расчет минимальных главных напряжений в грунтовом полупространстве // Вестник научных конференций. 2016. № 5-4 (9). С. 21-23.

21. Александров А.С., Долгих Г.В., Александрова Н.П. Расчет минимальных главных напряжений в слое конечной толщины // Вестник научных конференций. 2016. № 5-4 (9). С. 23-24.

(C) 2016, Долгих Г.В., Калинин А.Л. Применение оригинального эмпирического критерия Г.К. Арнольда для расчета безопасных давлений на грунт земляного полотна
(C) 2016, Dolgikh G.V., Kalinin A.L.

The use of original empirical criterion G.K. Arnold to calculate safe pressure on the soil subgrade 